\title{
The Herculean Echoes in Frankenstein
}

\author{
Han Ji \\ Beijing Union University \\ Beijing, China
}

\author{
Jiezhen Niu* \\ Beijing Union University \\ Beijing, China \\ *Corresponding Author
}

\begin{abstract}
Many critics have discussed the echoes of Faust and Prometheus in Mary Shelley's masterpiece Frankenstein, the Modern Prometheus, exploring the limits of ambition and rebelliousness and their moral implications. However, there is a mythological resemblance in this novel that has received almost no critical comment. In many ways, Victor's forlorn and unnatural creature offers poignant echoes of Hercules, the greatest and most fearsome of all the heroes in the Greek mythology, yet also one of the loneliest and most tragic figures in the Western canon.
\end{abstract}

\section{Keywords-Hercules; misfit; self-sacrifice; majestic}

\section{INTRODUCTION}

At the end of her journal entries for 1815, Mary Shelley lists the titles of seventy-five works that she read during the year, among them Gibbon's Decline and Fall of the Roman Empire, Pope's great translation of The Iliad, and Plutarch's Lives of the Noble Greeks and Romans. Many of the books are mentioned only once or twice in the daily entries in her journal, while others are not mentioned at all. However, one title is repeatedly mentioned, sometimes twice or even three times in a single day's entry: The Metamorphoses, Ovid's exhaustive first century AD compilation of classical myths. Shelley read The Metamorphoses, in the original Latin during 1815. So the next year, when she embarked on the task of expanding her brief, dream-inspired horror tale into a full-length novel - Frankenstein, The Metamorphoses - as well as her other classical readings - served as excellent sources for her frequent allusions to mythical Greek figures, Prometheus among the most obvious instances.

However, there is a mythological resemblance in Frankenstein that has received almost no critical comment. In many ways, Victor's forlorn and unnatural creature offers poignant echoes of Hercules, the greatest and most fearsome of all the heroes in the Greek mythology, yet also one of the loneliest and most tragic figures in the Western canon.

In her journal entries from 8 April to 13 May 1815, Shelley meticulously records her daily readings from The Metamorphoses, often listing the very number of lines completed. Therefore, her earnest attitude toward this book showed that Mary Shelley - as she began writing her first novel in 1816 - might utilize the Herculean tales in Ovid's work as a plot model. Besides, given Mary Shelley's admitted fascination with outcasts and vagabonds, misfits and anomalies, it seems clear that the touching stories of Hercules - a giant created in an unnatural way and left to fend for himself in a cruel world - definitely attract Mary Shelley.

Exploring the similarities between Victor's creature and Hercules will add a deeper layer to Shelley's masterpiece about a powerful creature set loose in the world by a cavalier and uncaring creator-father.

\section{BIRTH}

The most obvious similarity between Hercules and the creature is, of course, their imposing physiques. Both are gigantic, superhuman in size and strength. However, more importantly, both misfits are illegitimate and suffer horribly for it. Hercules, for example, was born a half-caste. According to Plutarch, this ill-gotten son of Zeus was formed "of half-blood amongst the gods, having had a mortal woman for his mother". In a world of normal humans, this huge Greek hybrid - although not deformed or physically ugly - ultimately proved to be a monstrous and destructive misfit. Because the tales of Hercules accumulated over many centuries and often were reinterpreted by succeeding generations to fit new tastes and preferences, there are, of course, differing versions of some of the important events in the heroic demigod's life. Most classical sources do, however, agree on one particular aspect concerning the origins of Hercules: he was delivered in the midst of a thunderstorm just as a blinding flash of lightning - the sacred calling card of Zeus - illuminated the earth and sky with supernatural fire, signaling the arrival of something or someone far from ordinary.

Likewise, Victor Frankenstein's giant creature is neither god nor man. He is a bastard son of science, an unnatural being brought to life completely formed. When Victor is fifteen years old, during "a most violent and terrible thunderstorm," he sees a magnificent tree shattered by a bolt of lightning: "and so soon as the dazzling light vanished the oak had disappeared, the nothing remained but a blasted stump". This accident is crucial in the young scholar's life: it is what inspires him to seek the very origins of creation in the white heat of electricity. Therefore, Victor's creature is born in a flash of lightning exactly like Hercules.

\section{TEMPERAMENT}

Despite many changes to Herculean myths down the centuries, there are several constants. Classical sources agree, for instance, that during his short life, this giant demigod was governed by passion, consumed by guilt, and frequently 
lacking in self-discipline. In The Metamorphoses, Hercules has great difficulty "controlling his flaring rage," often destroying life and property in childlike fits of anger that he later deeply regretted. In short, Hercules often acted as a temperamental man-child who just happened to have the strength of a Titan. According to G. Karl Galinsky in The Herakles Theme: Adaptations of the Hero in Literature from Homer to the Twentieth Century, the brief and mostly unhappy life of Hercules symbolized "[m]an choosing between good and bad, man struggling for a decent fate in a hostile universe". Such epic themes apply equally well to Victor's creature, whose short life span - only about four years - is a constant struggle to find his place in a cold and callous world.

Zeus, the absent creator-father, did not help raise Hercules, did not teach him right from wrong or instruct him. In fact, the supreme ruler of all Olympus cruelly abandoned his son immediately after birth, refusing to accept the manifold responsibilities of fatherhood. To protect his Olympian pride, Zeus even tried - though unsuccessfully to keep the birth of his problematical child from Hera and the other divines. Likewise, Victor - behind his fiancée's back violates nature, "gives birth to" a son, and then tries desperately to hide him from family and friends, because, as Chris Baldick observes, "his monster is a very private enterprise, conducted in the shadow of guilt and concealment". In effect, Zeus and Victor both "cheat" on their women, then try vainly to avoid the unpleasant consequences of their actions. Plus, in perfect keeping with Greek morality, their sins are visited on their sons. In short, neither Hercules nor the monster has a nurturing father or a normal childhood. Both nonsocialized misfits are cast adrift without the guidance of family structure or moral instruction. As a result, they must struggle through life on their own, searching for personal identities.

In The Metamorphoses, Ovid describes Hercules as a fearless hero who faced all challenges head-on. According to Crowell's Handbook of Classical Literature, Hercules, especially in the earliest versions of the myths, was "best known for his course and his amazing physical strength". The Oxford Companion to Classical Literature attributes "endurance, good nature, and compassion" to the Herculean traits that have been celebrated down the centuries. However, this neglected son of Zeus was forced to "endure the burden of great toil and danger and agonizing personal sorrow" throughout his entire existence. Such powerful descriptions of woe are matched by the monster's short and lonely life as an outcast, a wanderer. After a violent fit of madness, Hercules was forced to perform the Twelve Labors as punishment for murdering "Megara [his first wife] and his children under the delusion that they were his enemies". In parallel, Victor's creature loses a wife and kills a wife - the former his own, the latter his creator's. The monster then imposes his own painful punishment as he wanders across the whole of Europe and then into the barren Arctic, enduring great loneliness and abuse as the he goes because like Hercules - the creature "is not only conscious of the wrong done him but also aware of his guilt".
Despite his unpredictable temperament and childlike naivety, Hercules was, when given the opportunity, kind and generous. For example, Galinsky describes how "the predominant part of the tradition emphasized Herakles's use of his strength for [...] the common good". In much the same way, the monster prefers to do charitable deeds, becoming violent only after maltreatment: "'I was benevolent and good; misery made me a fiend"'. In fact, so tender is his character that he cannot bring himself to slaughter animals for food. Thus, during his four-year life span, he is a strict vegetarian: "II do not destroy the lamb and the kid to glut my appetite; acorns and berries afford me sufficient nourishment". Because he does not know his own strength, the creature's first killing - the strangulation of young William Frankenstein - is a tragic accident, not willful murder. As he tries to kidnap the little boy, he gently explains, "'I do not intend to hurt you". This unintentional killing is analogous to the many accidental deaths caused by Hercules. In one typical example, an adolescent Hercules, reproached for striking a sour note on his lyre, smashed the instrument over the head of his music teacher, killing the poor man instantly. In another instance, while attending a banquet in his honor, the hungry giant, reaching for a platter of food, crushed the unfortunate guest next to him with an errant elbow.

\section{DEATH}

No matter how desperately they effort to fit in, Hercules and the monster never find a niche (shelter) in human society. According to Ovid, toward the end of his life, after years of pain and penance, loneliness and loss, Hercules begged the Olympian gods for mercy, for release: "II am so wretched an object, [...] take away this cruelly tortured, hateful soul, that was born for toill'". Indeed, the final and the most obvious resemblance between Zeus's son and Victor's monster is the manner in which they die.

Although both Hercules and the creature can be wounded, sometimes gravely, neither can be killed outright, at least not by any human foe. As a result, when they finally grow tied of life and decide to end it, they are the only ones who can strike themselves down, can extinguish with elemental fire the glowing spark of an unnatural life. According to Ovid's moving account, at the end of his days, haunted by his many murders and suffering from agonizing wounds,

Hercules, the renowned son of [Zeus], cut down the trees which grew on lofty Oeta and built them into a pyre. [...] he kindled the pyre and, while the greedy flames were taking hold on the pile, laid the skin of the Nemean lion on top of the heap of tree-trunks and lay down, his neck resting on his club, and on his face an expression no different from that of a guest, reclining among the winecups, with garlands on his head.

Moments later, continues The Metamorphoses, as the great but tragic soul of Hercules rose from the all-consuming flames, Zeus, the long-absent father, flew down from high Olympus and swept his son's spirit "up through the hallow clouds in his four-horse chariot and set him among the glittering stars". Wrought at the end of so short and painful a life, this honorable suicide transferred the Greek demigod 
from a lonely and destructive outcast into what Ovid calls as "a majestic figure of august dignity".

Such a tranquil embracing of death as a release, as a return to peaceful oblivion, is closely echoed when Victor's creature describes his own plans for self-sacrifice to Captain Robert Walton, the Arctic recorder for both the monster and his maker: "My work is nearly complete. Neither yours nor any man's death is needed to consummate the series of my being, and accomplish that which must be done; but it requires my own. Do not think that I shall be slow to perform this sacrifice. [...] I shall collect my funeral pile and consume to ashes this miserable frame". The creature then declares that in suicide " "must I find my happiness. [...] it is my only consolation. [...] Polluted by crimes, and torn by the bitterest remorse, where can I find rest but in death?"'

On the last page of the novel, as he stands over the wasted corpse of his creator-father, racked with guilt and finally aware of the tremendous harm he has inflicted upon so many innocents, the monster describes how he will atone for his sins: "I shall ascend my funeral pile triumphantly, and exult in the agony of the torturing flames. The light of that conflagration will fade away; my ashes will be swept into the sea by the winds. My spirit will sleep in peace; or if it thinks, it will not surely think thus. Farewell"'. With those memorable last words, the friendless creature leaps through the cabin window and onto a nearby ice floe. According to Captain Walton, the tragic giant is "soon borne away by the waves, and lost in darkness and distance". As he goes to meet his fiery doom, the poignant image of the lonely creature on the ice floe being swallowed up by the Arctic fog still echoes permanently down many generations since the novel's first publication in 1818. This is similar to the moving image of a lonely Hercules being enveloped by clouds of white smoke in Western myth. In the end, the creature's self-cremation should be interpreted as precisely what Mary Shelley intended it to be a very Herculean suicide, not at the summit of Mount Oeta, but at the North Pole - the very summit of the world. Like a good and honorable Greek, the monster will mount his great funeral pyre and, in death, gain his own form of "august dignity." After a short life of pain, loneliness, and despair, the outcast and illegitimate son of Victor Frankenstein will find, in the annihilating flames, the eternal peace.

\section{CONCLUSION}

In conclusion, a mythological resemblance is indicated in Shelly's Frankenstein. In many ways, Victor's forlorn and unnatural creature offers poignant echoes of Hercules, the greatest and most fearsome of all the heroes in the Greek mythology, yet also one of the loneliest and most tragic figures in the Western canon.

\section{REFERENCES}

[1] Baldick, Chris. In Frankenstein's Shadow: Myth, Monstrosity, and Nineteenth Century Writing. NY: Oxford UP, 1987, p.51.

[2] Feder, Lillian. Crowell's Handbook of Classical Literature. NY: Harper, 1964, p.31, p.161
[3] Galinsky, G. Karl. The Herakles Theme: Adaptations of the Hero in Literature from Homer to the Twentieth Century. Totowa, NJ: Rowman, 1972, p185, p4.

[4] Howatson, M. C., ed. The Oxford Companion to Classical Literature. 2nd ed. Oxford: Oxford UP, 1989, p269, p270.

[5] Ovid. The Metamorphoses. Trans. Mary M. Innes. London: Penguin, 1955, pp.185-210.

[6] Plutarch. Plutarch's Lives of the Noble Greeks and Romans. Trans. John Dryden. Ed. Edmund Fuller. Garden City: International Collectors Lib., 1959, p.93.

[7] Shelley, Mary. Frankenstein. 1831. NY: Modern Lib., 1984.

[8] Mary Shelley's Journal. Ed. Frederick L. Jones. Norman: U of Oklahoma P, 1947.

[9] Thornburg, Mary K. Patterson. The Monster in the Mirror: Gender and the Sentimental/Gothic Myth in Frankenstein. Ann Arbor: UMI Research, 1987, p.119. 